\title{
Structural behavior of load bearing brick walls of soil-cement with the addition of ground ceramic waste
}

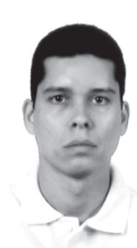

Humberto C. Lima Júnior ${ }^{1}$, Fábio L. Willrich ${ }^{1} \&$ Normando P. Barbosa ${ }^{2}$

\author{
1 Laboratório de Modelos Reduzidos/CCET/UNIOESTE. Rua Universitária 2069, CEP 85814-110, Cascavel, PR. \\ Fone: (45) 220-3221. E-mail: correialima@unioeste.br (Foto) e flwillrich@unioeste.br \\ 2 CT/UFPB. CEP 58059-900, João Pessoa, PB. Fone: (83) 246-2669. E-mail: npperazzo@lsr.ct.ufpb.br
}

Protocolo 136 - 12/9/2002 - Aprovado em 8/10/2003

\begin{abstract}
An experimental study of three load bearing walls is presented and discussed in this paper. The walls were of soil-cement bricks made with three different material proportions, in which two of them had part of the cement amount replaced by crushed ceramic waste. The walls were $95.20 \mathrm{~cm}$ high, $75.32 \mathrm{~cm}$ wide and $12.56 \mathrm{~cm}$ thick and had their bricks layered with cement paste. The walls were tested under compression and their displacements were measured with 5 dial gages. The walls had satisfactory behaviour and their strengths were suitable as required by Brazilian popular houses. The differences between the brick strength and the wall strength were less than $20 \%$. A finite element analysis (FEA) was performed and the uniformity of the compressive stress distributions in the walls was evaluated. Finally, it was observed that the partial replacement of the cement by crushed ceramic waste is possible.
\end{abstract}

Key words: load bearing wall, ceramic waste, soil-cement

\section{Comportamento estrutural de paredes estruturais de tijolos de solo-cimento com adição de resíduo cerâmico moído}

\begin{abstract}
Resumo: Neste trabalho, apresenta-se resultados do estudo experimental de três paredes estruturais, construídas com tijolos de solo-cimento. Os tijolos foram fabricados com três diferentes proporções de materiais, nas quais duas delas tiveram parte do cimento substituído por resíduo cerâmico moído. As paredes apresentavam altura de 95,20 cm, largura de 75,32 cm e espessura de $12,56 \mathrm{~cm}$ e tiveram seus tijolos rejuntados com pasta de cimento, que foram ensaiadas sob compressão centrada e tiveram seus deslocamentos avaliados por cinco relógios medidores de deslocamento. Observou-se comportamento estrutural satisfatório e resistências compatíveis com as requeridas pelas paredes das casas populares brasileiras. Em todos os casos, as diferenças entre as tensões máximas nas paredes e as resistências dos tijolos, foram inferiores a $20 \%$. Para concluir o estudo, realizou-se análise por meio do método dos elementos finitos (MEF) com o intuito de avaliar a uniformidade na distribuição das tensões ao longo das paredes. Finalmente, observou-se que a substituição parcial do cimento na fabricação de tijolos de solo-cimento é viável.
\end{abstract}

Palavras-chave: paredes estruturais, rejeito cerâmico, solo-cimento

\section{INTRODUCTION}

One of the serious problems faced by the population in the developing countries is the lack of dignified habitation, which is caused by the high prices of the usual construction materials and the unfair income distribution. Due to these facts, some researchers are trying to recover the earth construction techniques. The use of earth as building material dates back to at least the Ubaid period in ancient Mesopotamia (5000-4000 B.C.), where a plastic mixture of clayey soil with a binding agent, such as straw, was used (Heathcote \& Ravindrarajah, 2000).
After the Second World War, the interest of earth construction up surged and the basic principles of soil stabilised with cement were established (Freire, 1976). Nevertheless, in the recent years the use of cement as a stabilising material has been recriminated due to environmental problems. This fact has made several research projects been retaken, trying to replace the cement by other mineral additions, such as: fly ash, rice husk ash, silica fume, metakaonlin, etc (Rolim \& Freire, 1998 and Akasaki \& Silva, 2001). All these mineral additions have several silica and aluminium in amorphous form, which can react chemically with the lime that comes from the cement hydration, to form similar composites to the silicates and 
aluminates of calcium hydrate. This reaction is named pozzolanic reaction and can improve the mechanical properties of the soil and decreases the $\mathrm{pH}$ of this material, which is important when natural fibres are used.

Other mineral additions used replacing cement do not have pozzolanic activity; nevertheless, because of the high fineness, their particles can fill the voids between the cement particles, increasing the soil density and strength. This effect is named as filler effect. The biggest advantage of the use of these mineral additions is that the great majority of these materials are industrial waste.

Ceramic waste, from the constructions and brick factories, is one of these materials that can be used to stabilise the soil (Ay \& Ünal, 2000). Nowadays, $90 \mathrm{~kg}$ per habitant of ceramic waste is produced in Brazil and almost $99 \%$ of this amount is thrown away in the environment without any treatment (Pinto, 1999). In general, when crushed, this material presents physical and chemical composition to be used as mineral addition with Portland cement according to ASTM (1992).

The aim of the present work is to analyse the structural behaviour of load bearing walls made with soil-cement bricks, where cement amount was partially replaced by crushed ceramic waste. Three material proportions, to cast the bricks, were calculated based on Dallacort et al. (2002). The referred paper presents a methodology and some equations to find out the exact material proportion, as well as, the cement amount that can be replaced by crushed ceramic waste, for a required soilcement strength. Three walls were cast, one for each material proportion, and tested under compression. Load-displacement curves are presented and discussed, and a finite element analysis (FEA) was performed to evaluate the stress distribution in the walls.

\section{Soil}

\section{MATERIAL AND METHODS}

Disthrophic lateritic soil (oxysol) was used. This soil is formed by intense leaching, with an acid $\mathrm{pH}$ and high contents of iron and aluminium oxides. A sample of $1200 \mathrm{~kg}$ was collected and the superficial layer of $60 \mathrm{~cm}$ was rejected because of presence of the organic material. The soil was left to dry over a plastic sheet for one month. As the amount of clay was high, a granulometric correction was done. This correction consisted of mixture of $35 \mathrm{~kg}$ dry soil with $65 \mathrm{~kg}$ quartz sand with fineness modulus of 2.1, maximum size of $2.4 \mathrm{~mm}$ and specific mass of $2650 \mathrm{~kg} \mathrm{~m}^{-3}$. The mixture was performed in a $250 \mathrm{~L}$ mechanical batch, for a period of $10 \mathrm{~min}$. Afterwards, six soil samples were collected and granulometric analysis, liquid limit and the plasticity limit were determined according to NBR 7181 (ABNT, 1984c), NBR 6459 (ABNT, 1984a) and NBR 7180 (ABNT, 1984b), respectively. The soil granulometric curve is presented in Figure 1. The liquid and plasticity limit, as well as, the plasticity index were $19.01,11.96$ and $7.05 \%$, respectively.

\section{Binding materials}

Initial high strength Portland cement was used. This cement presents high fineness and is made of Portland clinker, gypsum, limestone filler and pozzolanic material. Its physical and chemical characteristics are presented on Table 1.

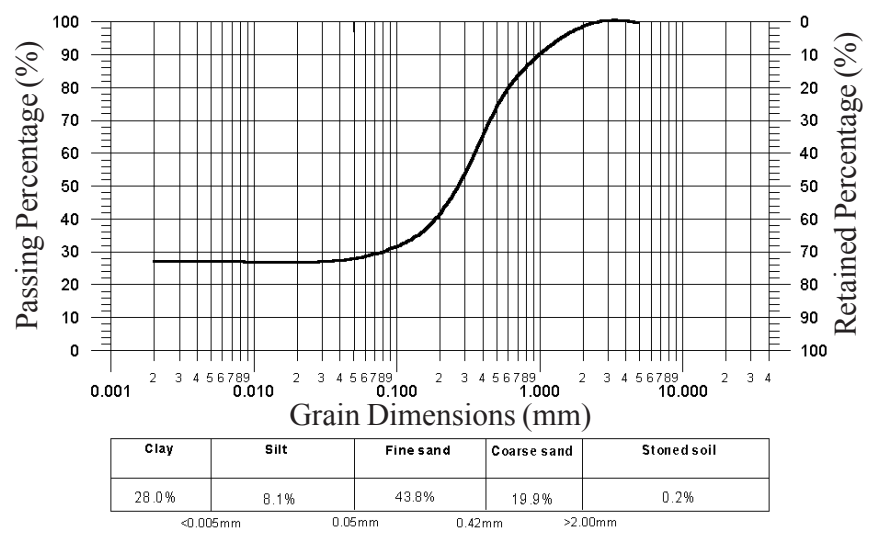

Figure 1. Granulometric curve of the soil mixture

Table 1. Physical and chemical properties of the cement

\begin{tabular}{|c|c|}
\hline Characteristics & Value \\
\hline Retained Percentage ABNT $n^{\circ} 20075 \mu \mathrm{m}(\%)$ & 0.08 \\
\hline Retained Percentage ABNT $\mathrm{n}^{\circ} 32545 \mu \mathrm{m}(\%)$ & 1.76 \\
\hline Blaine fineness $\left(\mathrm{cm}^{2} \mathrm{~g}^{-1}\right)$ & 4339.00 \\
\hline Setting time - Initial (min) & 184.00 \\
\hline Setting time - Final ( $\mathrm{min})$ & 261.00 \\
\hline Autoclave expansion (mm) & 0.00 \\
\hline Compressive strength (MPa) - 1 day & 26.50 \\
\hline Compressive strength (MPa) - 3 days & 40.50 \\
\hline Compressive strength (MPa) - 7 days & 43.10 \\
\hline Compressive strength (MPa) -28 days & 54.10 \\
\hline Specific mass $\left(\mathrm{g} \mathrm{cm}^{-3}\right)$ & 3.130 \\
\hline Ignition loss $(\%)$ & 2.88 \\
\hline $\mathrm{C}_{2} \mathrm{~S}(\%)$ & 5.44 \\
\hline $\mathrm{C}_{3} \mathrm{~S}(\%)$ & 64.58 \\
\hline $\mathrm{C}_{3} \mathrm{~A}(\%)$ & 6.78 \\
\hline $\mathrm{CaO}$ free & 0.73 \\
\hline $\mathrm{MgO}$ free & 1.99 \\
\hline $\mathrm{K}_{2} \mathrm{O}(\%)$ & 0.81 \\
\hline $\mathrm{Na}_{2} \mathrm{O}(\%)$ & 0.03 \\
\hline $\mathrm{SO}_{3}(\%)$ & 3.00 \\
\hline Insoluble residue $(\%)$ & 0.34 \\
\hline
\end{tabular}

The waste ceramic material was comprised of ceramic bricks, which were rejected by the quality control because of small cracks caused by the burning process. The bricks were burned at a temperature between 800 and $900^{\circ} \mathrm{C}$ for a period of $10 \mathrm{~h}$. After being selected, the bricks were crushed and sieved through a $50 \mu \mathrm{m}$ and only the passing material was used. The chemical analysis of the crushed bricks is presented in Table 2 and the $\mathrm{x}$ ray diffractogram in Figure 2. The chemical analysis was carried out by $\mathrm{x}$-ray spectrophotometer. The chemical composition showed that the contents of $\mathrm{SiO}_{2}+\mathrm{Al}_{2} \mathrm{O}_{3}+\mathrm{Fe}_{2} \mathrm{O}_{3}-91.8 \%, \mathrm{MgO}$ $-0.3 \%, \mathrm{SO}_{3}-0.04 \%$ and $\mathrm{CaO}-0.6 \%$, which were in accordance with the limits established by ASTM (1992) for mineral addition using Cement Portland mixtures. The pozzolanic activity index according to NBR - 5752 (ABNT, 1992) was $84.21 \%$. The x-ray diffractogram indicates the presence of quartz, hematite and feldspar; and amorphous material is observed at the angles of $2^{\circ}, 16^{\circ}$ and $30^{\circ}$.

\section{Soil cement bricks}

The material proportions and the ideal soil moisture, to cast the soil cement bricks, were calculated based on Dallacort et al. (2002), who used soil cylindrical specimens with $10 \mathrm{~cm}$ diameter 
Table 2. Physical and chemical characteristics of the ceramic material

\begin{tabular}{lr}
\hline Characteristic & Value \\
\hline $\mathrm{Na}_{2} \mathrm{O}(\%)$ & 0.064 \\
$\mathrm{MgO}(\%)$ & 0.300 \\
$\mathrm{Al}_{2} \mathrm{O}_{3}(\%)$ & 26.000 \\
$\mathrm{SiO}_{2}(\%)$ & 58.000 \\
$\mathrm{P}_{2} \mathrm{O}_{5}(\%)$ & 0.071 \\
$\mathrm{SO}_{3}(\%)$ & 0.040 \\
$\mathrm{~K}_{2} \mathrm{O}(\%)$ & 0.290 \\
$\mathrm{CaO}(\%)$ & 0.600 \\
$\mathrm{TiO}_{2}(\%)$ & 6.600 \\
$\mathrm{MnO}(\%)$ & 0.047 \\
$\mathrm{FE} \mathrm{O}_{3}(\%)$ & 7.800 \\
$\mathrm{NiO}(\%)$ & 0.013 \\
$\mathrm{CuO}(\%)$ & 0.029 \\
$\mathrm{ZnO}(\%)$ & 0.011 \\
$\mathrm{Y}_{2} \mathrm{O}_{3}(\%)$ & 0.039 \\
$\mathrm{ZrO}_{2}(\%)$ & 0.077 \\
$\mathrm{Cr}_{2} \mathrm{O}_{3}(\%)$ & 0.032 \\
$\mathrm{Blaine}(\%)$ fineness $\left(\mathrm{cm}^{2} \mathrm{~g}^{-1}\right)$ & 4136.000 \\
$\mathrm{Specific} \mathrm{mass}\left(\mathrm{kg} \mathrm{m}^{-3}\right)$ & 2.660 \\
$\mathrm{Passing}^{-3}$ percentage - $-50 \mu \mathrm{m}(\%)$ & 100.000 \\
\hline
\end{tabular}

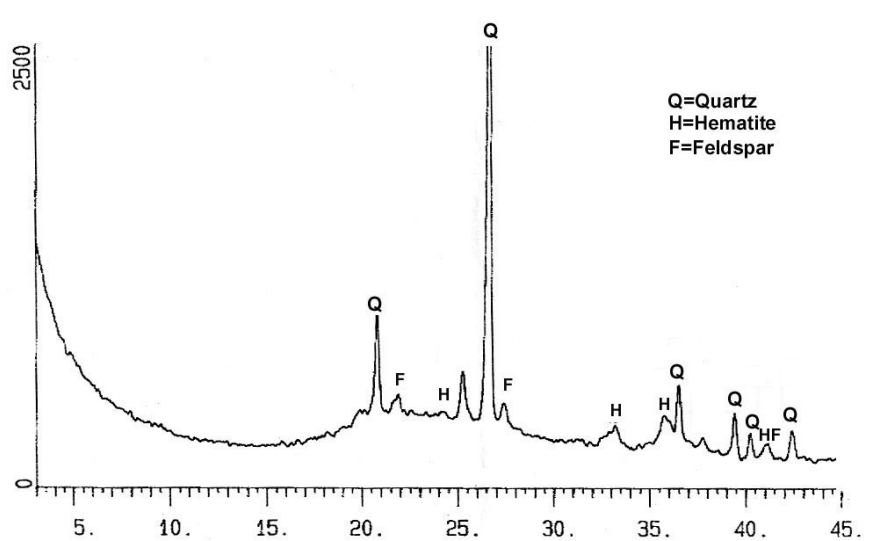

Figure 2. X-ray diffractogram of the crushed ceramic waste

and $20 \mathrm{~cm}$ high, compacted in three layers by 25 beats of the Proctor hammer each, to evaluate the soil compressive strength. Three material proportions were used: mixture $1-15.8 \%$ of soil moisture, $6 \%$ of binding material and without any replacement of Portland cement by crushed ceramic material; mixture 2 $15.8 \%$ of soil moisture, $6 \%$ of binding material and $35 \%$ of replacement of Portland cement by crushed ceramic material; and mixture $3-15.8 \%$ of soil moisture, $8 \%$ of binding material and $55 \%$ of replacement of Portland cement by crushed ceramic material. Still, according to Dallacort et al. (2002), the mixtures 1,2 and 3 correspond to soil cylindrical specimens with compressive strengths of 4.8, 3.3 and 3.3 MPa, respectively, which give brick compressive strengths of 3.5, 2 and $2 \mathrm{MPa}$. This difference between the cylindrical and the brick strength is due to the difference in the compacting energies used to mould the cylinders (dynamic compactness) and the bricks (static compactness).

The raw materials were mixed in a batch of $250 \mathrm{~L}$ for a period of $10 \mathrm{~min}$. The bricks were made on a manual steel press, which is able to compress the soil with an average pressure of 2.75 MPa. For each mixture, a hundred bricks and two soil cylindrical specimens with $10 \mathrm{~cm}$ diameter and $20 \mathrm{~cm}$ high were prepared. The cylindrical specimens were compacted in a steel mould in three layers by 20 beats of the Proctor hammer, following the same approach used by Dallacort et al. (2002). This procedure had the objective to evaluate the methodology of referred authors. In the end, the bricks and the cylindrical specimens were covered by a plastic sheet for a period of seven days, during which were watered twice a day and, after the curing period, were left to dry in the shadow for a period of 21 days.

Three bricks of each mixture were collected for compressive test. The bricks were weighed, their dimensions were measured, and sawed at the width centre point. Afterwards, these 2, brick parts were flushed with cement paste, one on the top of the other, and the resulting specimens had their top and bottom surface capped with a thin layer of cement paste. The brick geometric characteristics and the brick specimen for compressive test are presented in Figures 3 and 4, respectively.

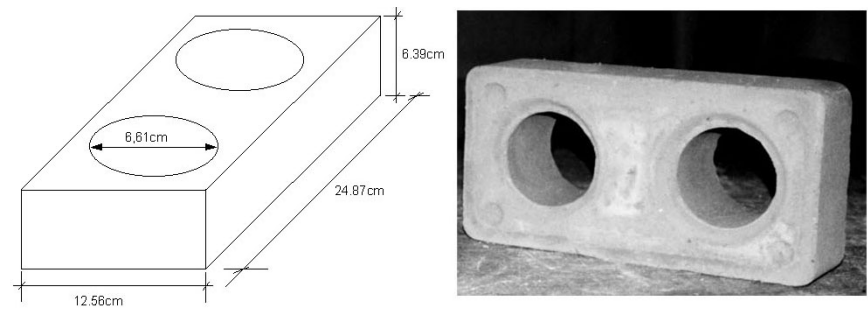

Figure 3. Brick geometric characteristics

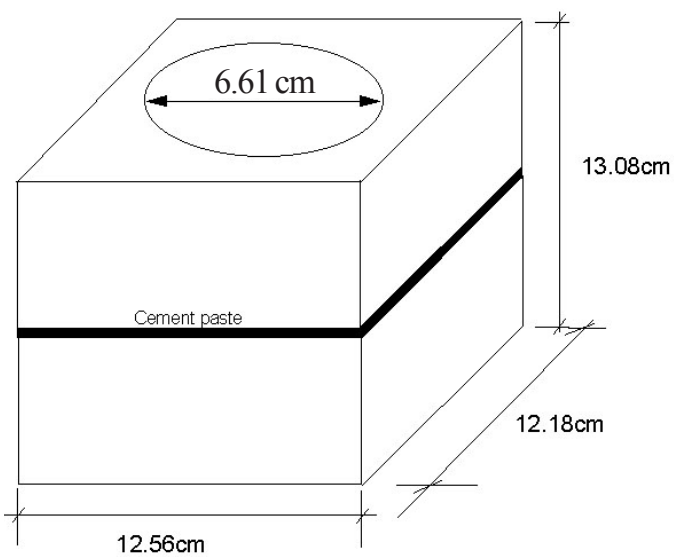

Figure 4. Compressive brick specimen

The compressive tests for the bricks and the cylinder were performed on the same day of the wall tests, which was conducted 34 days after casting. Before testing, the cylinders were weighed and then had their end surfaces capped with a thin sulphur layer. The compressive test was done in a stiffness machine with load capacity of $1000 \mathrm{kN}$. A load cell of $50 \mathrm{kN}$ was connected to the system and data were fed to a data acquisition system. A teflon sheet of $0.4 \mathrm{~mm}$ thickness was placed between the specimens and the steel plates. The load was applied at a rate of $0.5 \mathrm{kN} \mathrm{s}^{-1}$. Only in the cylinder specimens, a clip gage was used to quantify the specimen strains. The brick strains were not measured due to the cement paste interference. The compressive test set-up is shown in Figure 5.

\section{Brick walls}

Three walls were made, one for each kind of brick and were numbered according to the number of the soil-cement mixture 


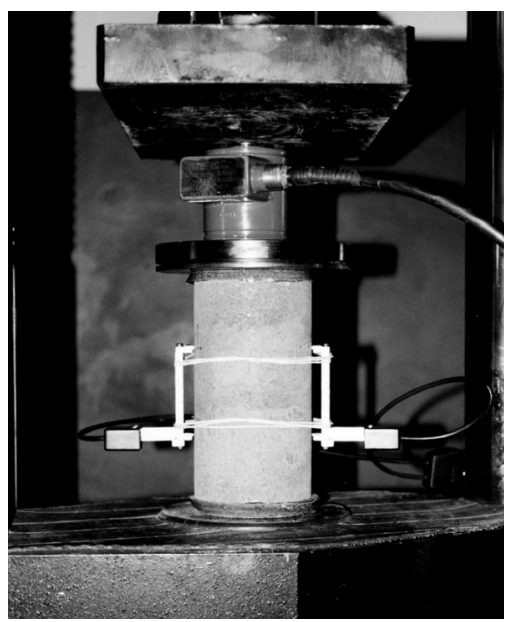

Figure 5. Compressive test set-up

used to cast the bricks. They were built on a reinforced concrete reaction table and were $95.20 \mathrm{~cm}$ high, $75.32 \mathrm{~cm}$ large and 12.56 $\mathrm{cm}$ thick. The bricks were flushed with cement paste, so that, the thickness of the cement paste layers were less than $3 \mathrm{~mm}$. On the wall tops, a reinforced concrete stiff beam was cast to distribute the applied load uniformly. On the front and back wall side a piece of wood with hinges was placed to prevent lateral displacement. The wall characteristics are shown in Figure 6.
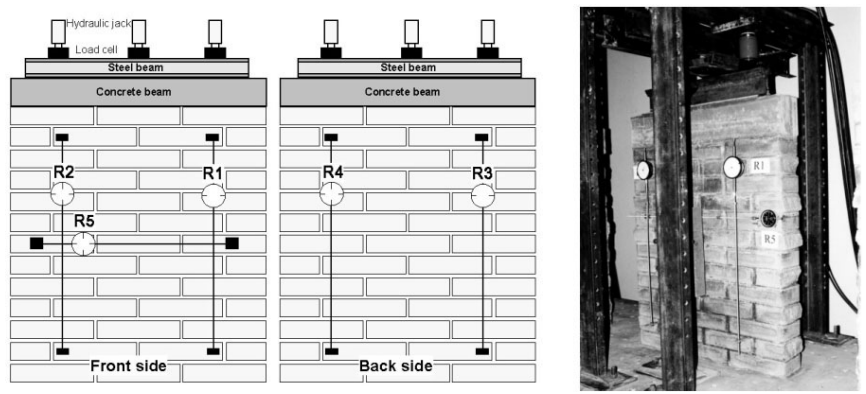

Figure 6. Wall details and test set-up

Five dial gages instrumented the walls: one measuring the lateral expansion in the width; and four measuring the compression strain in the height (two dial gages on the front side and two on the back side of the wall). The dial gages were connected to the walls by steel plates screwed into the wall and were numbered according to Figure 6 . The distance between the dial gages 1,2, 3 and 4, and the wall surface was approximately $5.43 \mathrm{~cm}$, and between the dial gage 5 and the wall was approximately $2.10 \mathrm{~cm}$. The strain evaluation length was the same for all dial gages and was approximately $65 \mathrm{~cm}$.

The load was applied with three hydraulic jacks connected to a steel frame. A stiff steel beam was placed on the top of the concrete beam to distribute the load. Load cells were connected to each hydraulic jack and data were fed to a data acquisition system. The three jacks were linked to the same hydraulic system, which guaranteed the same oil pressing on the jacks and consequently, the same applied load. The load was applied in steps of $10 \mathrm{kN}$ in three cycles: the first one went from 0 to 20 to $0 \mathrm{kN}$, the second from 0 to 40 to $0 \mathrm{kN}$, and the last from $0 \mathrm{kN}$ to the collapse. Each step load was maintained for a period of about $5 \mathrm{~min}$.

\section{RESULTS AND DISCUSSION}

\section{Brick and cylindrical specimen strength}

The stress vs. strain curves, the average compressive strength and the tangent elasticity modulus of the cylindrical specimens for each mixture are presented in Figure 7. The cylindrical compressive strength of the mixtures 1,2 and 3 were 5.62, 3.84 and $3.14 \mathrm{MPa}$, respectively, and the average specific masses were 2024, 2001 and $1980 \mathrm{~kg} \mathrm{~m}^{-3}$, respectively. Although the difference between the ages of testing in this paper (34 days) compared to the Dallacort et al. (2002) (14 days), the difference between the experimental cylindrical strengths and those obtained according to referred authors were inferior to $20 \%$. It is observed that this difference is higher between the specimens with highest cement amount.

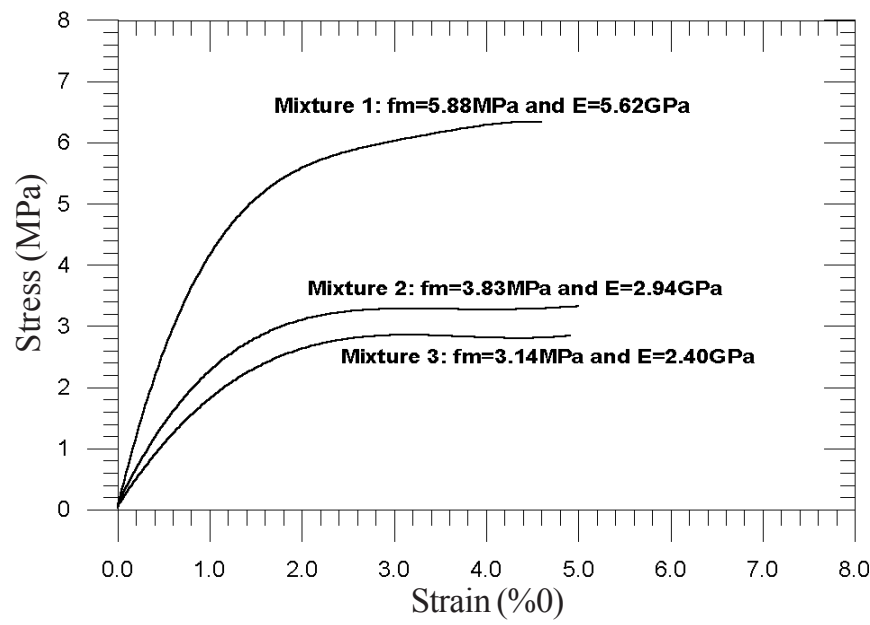

Figure 7. Stress vs strain curve for the cylindrical specimens

The average specific mass of the bricks made with the mixtures 1,2 and 3 were 1648,1689 and $1760 \mathrm{~kg} \mathrm{~m}^{-3}$, respectively, and the compressive strength of the bricks were 3.07, 2.11, $2.19 \mathrm{MPa}$, respectively. To calculate the brick compressive strength the net area was considered. The difference between the brick strengths and those calculated according to Dallacort et al. (2002) were less than to $12 \%$. In addition, it is observed that, in all cases, the brick compressive strengths were higher than the minimal strength required for Brazilian popular habitation that is $2 \mathrm{MPa}$ (Olivier et al., 1995).

\section{Wall test}

The compressive load vs. axial displacement curves for the walls 1, 2 and 3, respectively, are shown in Figures 8A, B and $\mathrm{C}$; in Figure 9, the load vs. lateral displacement curves of the three walls are presented and in Figure 10, the wall failure modes are shown.

The wall displacements through the height were corrected; they were measured $5.4 \mathrm{~cm}$ far from the wall side surface and due to the bending effect were amplified. The load system worked well and in all tests the differences among the load cell readings were inferior to $1.5 \mathrm{kN}$. The first cracks of the walls 

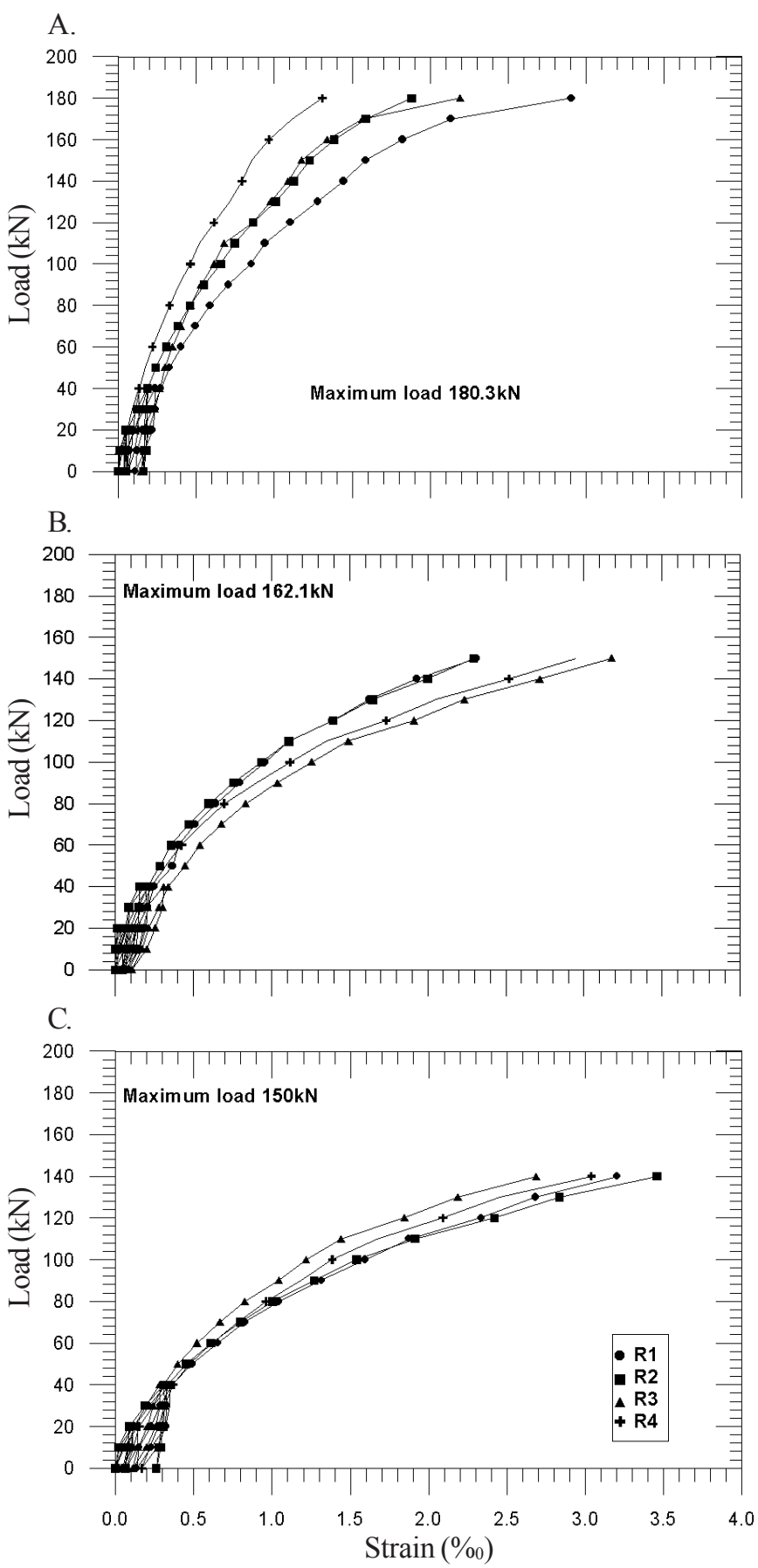

Figure 8. Wall 1 (A), 2 (B) e 3 (C)

were only visible close to the collapse load and the wall failures were characterised by an undesired sudden fragile mode. In all cases, the failures were reached with an approximated strain of $3 \%$ and the wall failure stresses were quite the same of the brick one, which is explained by the low slender index of the walls. Although the brick strengths of the mixture 2 and 3 were similar, the wall behavior was slightly different, with wall 2 showing more strength and stiffer than wall 3 . Because of the high cement content used to cast the bricks of wall 1, it presented the highest stiffness and strength among the walls.

The compressive stress, in wall 1, at the failure was 2.46 $\mathrm{MPa}$, which is $20 \%$ less than the brick strength. The strain gradient through the width was approximately $2 \%$, and through

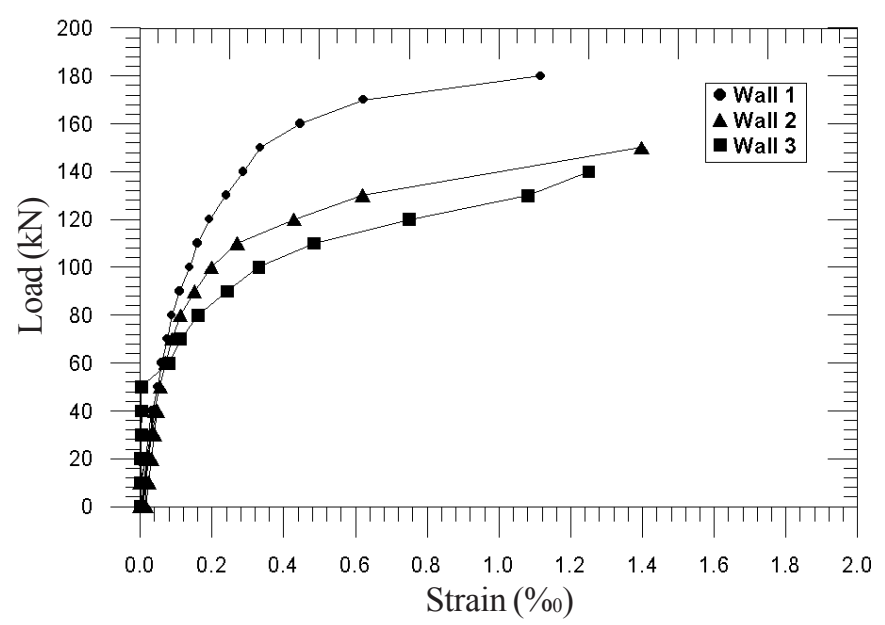

Figure 9. Lateral displacement of the walls (R5)

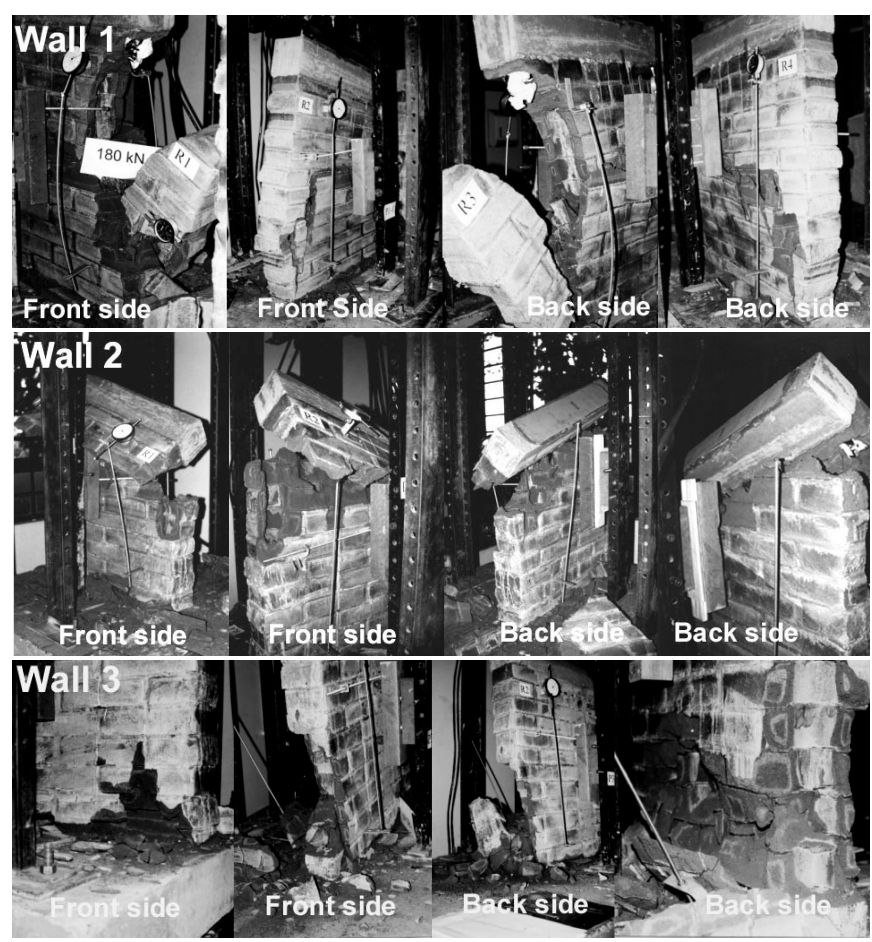

Figure 10. Wall failures

the thickness 1\%o. Despite this fact, the load cell readings did not accuse any difference among the loads applied by the jacks, and no eccentricity was detected before the test. The wall collapse began at the most compressive side (side of the dial gage 1) and was characterised by bending and compression modes. The wall transversal strain at the maximum load and at $50 \%$ of the maximum load were 54 and $17 \%$ of the longitudinal strain, respectively.

In wall 2, the compressive stress at the failure was 2.21 $\mathrm{MPa}$, which is almost the same brick strength. The gradient strain through the width was approximately null and through the thickness was approximately $1 \%$. Despite the small strain gradient presence, the wall collapse was characterised by only compression mode. The wall failure began at the side of the dial gages 3 and 4, almost at half height. The wall transversal strain at the maximum load and at $50 \%$ of the maximum load were 52 and $0.16 \%$ of the longitudinal strain, respectively. 
A.

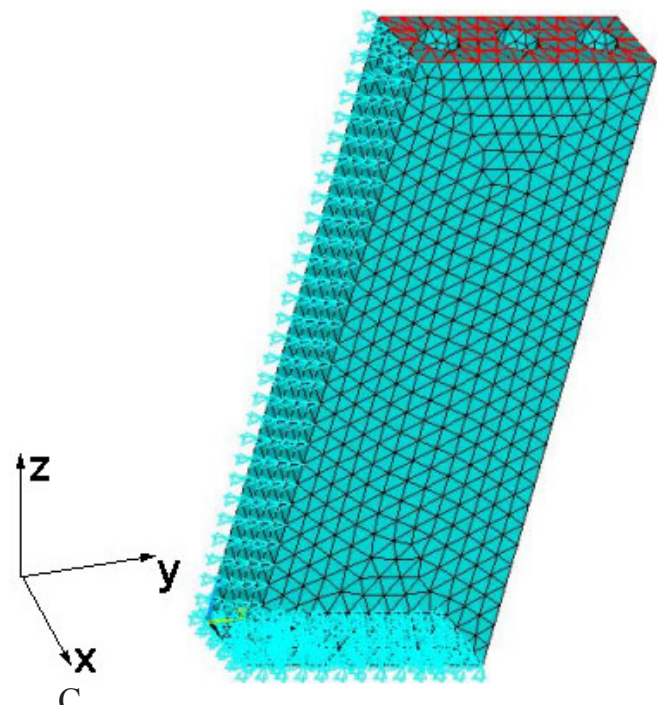

B.

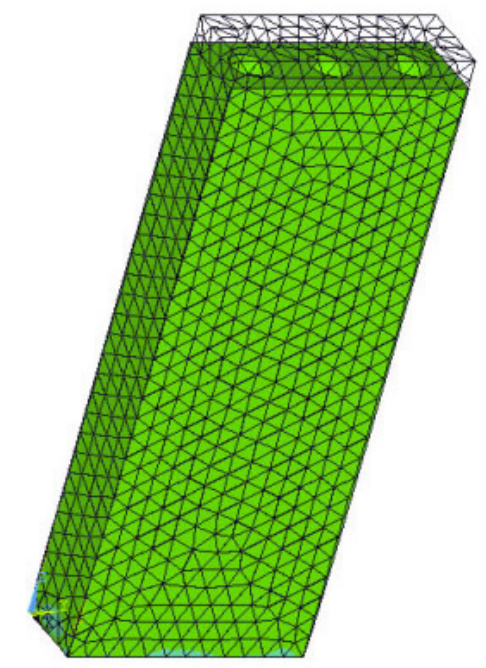

D.
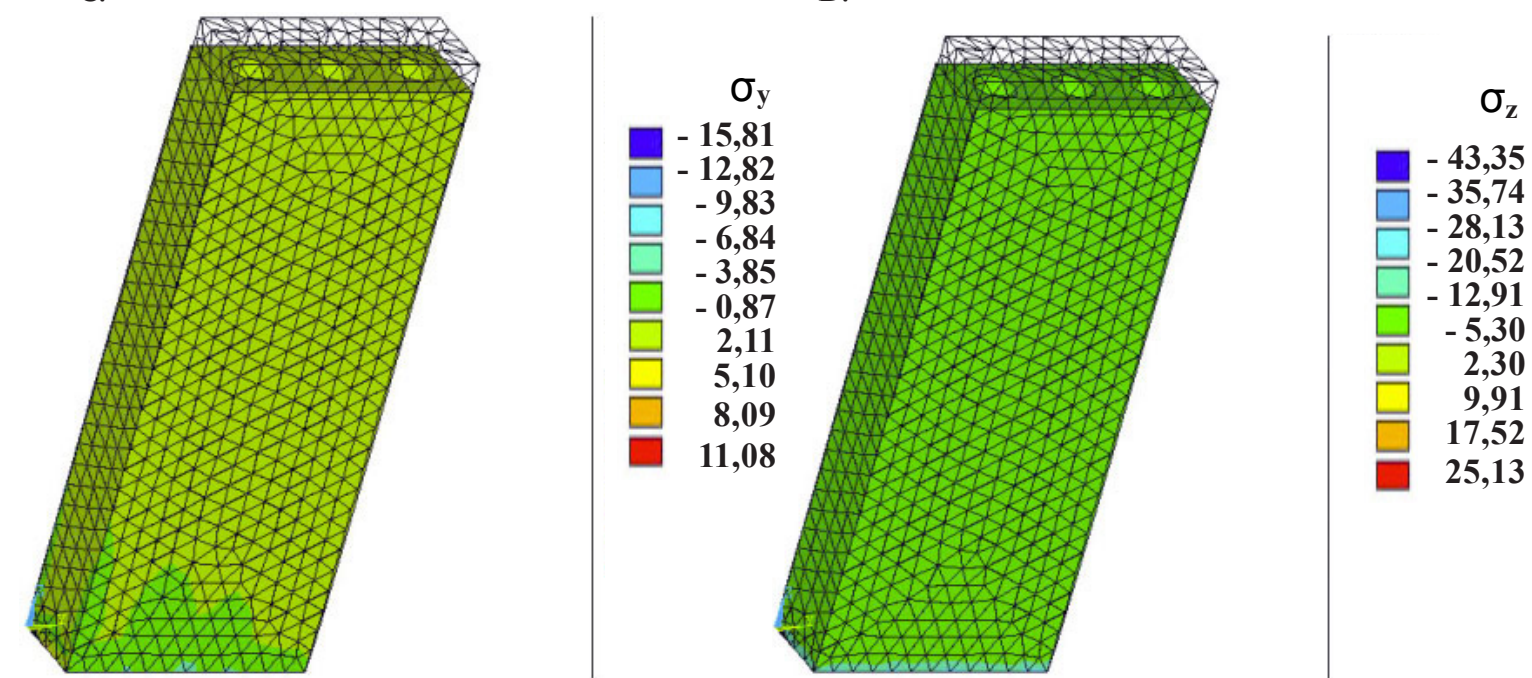

$\sigma_{\mathrm{x}}$

Figure 11. Finite element analysis: boundary condition and wall discretization (A), and the stress in axial direction X (B), Y (C) and $\mathrm{Z}(\mathrm{D})$ (stress units are is $\mathrm{kN} \mathrm{m}^{-2}$ )

In wall 3, the compressive stress at the failure was 2.05 $\mathrm{MPa}$, which is close to the brick strength. The gradient strain near collapse through the width was approximately $0.3 \%$, and through the thickness $0.5 \%$, which can be considered negligible. The wall failure mode was characterised by compression and the wall transversal strain at the maximum load and at $50 \%$ of the maximum load were 41 and $15 \%$ of the longitudinal strain, respectively. It is observed that the first cracks took place on the wall base and the collapse began at the front and back walls at the same time.

To evaluate if the stress distribution in the walls was uniform, a FEA was performed. This procedure was done because of the holes in the bricks, which can produce some stress concentrations and reduce the wall strength capacity. The analysis was elastic linear and was considered that the wall elasticity modulus and the Poisson coefficient were $2 \mathrm{GPa}$ and 0.2 , respectively. A tetrahedral solid element with 13 nodes and 3 degrees of freedom per node was used. The symmetry was used and only half wall was analysed. It was also considered that the wall was clamped on the reaction table. A surface load of $2000 \mathrm{kN} \mathrm{m}^{-2}$ was applied on the wall top. The results are presented in Figure 11. It is observed that the stress distribution is uniform and only in the $y$ direction a stress gradient caused by the boundary conditions can be observed. These observations confirm that the brick geometry is appropriate.

In a Brazilian popular house, with only one floor, the average maximum load on the wall varies from 1 to $10 \mathrm{kN} \mathrm{m}^{-1}$. Now, considering that the service load of the weakest wall, wall 3 , is $20 \%$ of the maximum load, which means approximately $40 \mathrm{kN} \mathrm{m}^{-1}$. It can be observed that this load is 4 times higher than the maximum load required in a popular habitation. In addition, considering a popular house with a room height of $2.4 \mathrm{~m}$ and the bricks elasticity modulus of $2.5 \mathrm{GPa}$, the wall buckling loads would be approximately between 20 and $90 \mathrm{kN} \mathrm{m}^{-1}$. Therefore, the brick strength increase is not important, since, the wall load capacity is also governed by the wall geometric stability. Based on these facts, it can be said that the bricks with $55 \%$ of cement replacement by crushed ceramic waste are suitable to be used as structural elements in popular housing. 


\section{CONCLUSIONS}

1. The methodology used to calculate the material proportions and the cement amount to be replaced by crushed ceramic waste was satisfactory.

2. The brick geometry produced a uniform stress distribution in the wall. In addition, the walls presented strengths compatible with those required by a usual Brazilian popular house.

3. Finally, it was observed that bricks with $55 \%$ of cement replacement by crushed ceramic waste are suitable to be used as structural elements in popular housing.

\section{ACKNOWLEDGEMENTS}

The authors are grateful to CIMEPAR for their kind cooperation at performing the chemical analysis of the crushed ceramic waste.

\section{LITERATURE CITED}

ABNT - Associação Brasileira de Normas Técnicas. NBR 6459 Ensaios de limite de liquidez. Rio de Janeiro, 1984a, 6p.

ABNT - Associação Brasileira de Normas Técnicas. NBR 7180 Ensaios de limite de plasticidade. Rio de Janeiro, 1984b, 3p.

ABNT - Associação Brasileira de Normas Técnicas. NBR 7181 Ensaios de granulometria por peneiramento e sedimentação. Rio de Janeiro, 1984c, 13p.

ABNT - Associação Brasileira de Normas Técnicas. NBR 5752 Materiais pozolânicos - Determinação de atividade pozolânica com cimento Portland - Índice de atividade pozolânica com cimento. Rio de Janeiro, 1992, 3p.

Akasaki, J.L.; Silva, A.P. Estudo de composições do solo estabilizado com cal e resíduos agroindustriais. In: Congresso Brasileiro de Engenharia Agrícola, 30, Foz do Iguaçu, PR, 2001. Foz do Iguaçu: SBEA, 2001. CD-Rom
ASTM - American Society of Testing and Materials. Fly ash and raw or calcined natural pozzolan for use as mineral admixture in Portland cement concrete. ASTM 618C. In: Annual Book of ASTM Standards, Philadelphia, USA, 1992, 3p.

Ay, N.; Ünal, M. The use of waste ceramic tile in cement production. Cement and Concrete Research, London, v.30, p.497-499, 2000.

Dallacort, R.; Lima Jr., H.C.; Willrich, F.L.; Barbosa, N.P. Resistência à compressão do solo-cimento com substituição parcial do cimento Portland por resíduo cerâmico moído. Revista Brasileira de Engenharia Agrícola e Ambiental, Campina Grande, v.6, n3, p.511-518, 2002.

Freire, W.J. Tratamento prévio do solo com aditivos químicos e seu efeito sobre a qualidade do solo-cimento. Piracicaba: Universidade de São Paulo - ESALQ, 1976, 142p. Tese Doutorado

Heathcote, K.A.; Ravindrarajah, R.S. Relationship between spray erosion tests and the performance of test specimens in the field. In: Sustainable construction into the next millennium: environmentally friendly and innovative cement based materials. João Pessoa, 2000, p.327-336.

Oliver, M.; El Gharbi, A.Z.; Adan, W. Proposition d'une norme déssai pour les blocs de terre comprimées. Lyon: Laboratory Geomataeriaux, ENTPE, 1995, 13p. Document provisoire de travail

Pinto, T.P. Metodologia para a gestão diferenciada de resíduos sólidos da construção urbana. São Paulo: Universidade de São Paulo, 1999, 189p. Tese Doutorado

Portland Cement Association. Soil primer. Illinois, 1976, 52p.

Rolim, M.M.; Freire, W.J. Resistência à compressão de tijolos fabricados com solo-vinhaça concentrada. Revista Engenharia Agrícola, Jaboticabal, v.17, n.3, p.1-8, 1988. 